\title{
Greek Catholic and Orthodox shrines in the Polish People's Republic as examples of destroying and saving the cultural heritage of the frontier
}

\author{
Roman Drozd
}

Prof. dr hab. Roman Drozd

Pomeranian University in Słupsk

Institute of History

Arciszewskiego 22 a

76-200 Słupsk

Poland

e-mail: roman.drozd@apsl.edu.pl

ORCID: 0000-0003-0169-7295

Muzeológia a kultúrne dedičstvo, 2021, 9:4:85-97

DOI: $10.46284 / \mathrm{mkd} .2021 .9 .4 .6$

Greek. Catholic and Orthodox shrines in the Polish People's Republic as examples of destroying and saving the cultural heritage of the frontier

The shrine constituting the centre of spirituality was inseparable from the religious life of the Ukrainian people. The deportations of Ukrainians from the south-east of Poland in 1944-1947 exposed their churches to intentional and unintentional devastation. The communist authorities aimed to erase the traces of Ukrainian people in that area therefore they were not interested in preserving the abandoned Greek Catholic shrines. What is more, they even encouraged their demolition. One way to save them was allowing them to be taken over by the Roman Catholic Church. However, it often involved a change to their interior décor. The best solution was allowing them to be taken over by the Orthodox Catholic Church, or transferring them to open-air museums as museum objects.

Keywords: Greek Catholic Church, Orthodox Catholic Church, shrines, Ukrainian people, Poland 1944 1989.

The resettlement of some Ukrainian people from Poland to the Russian Ukraine in the years 1944-1946, followed by the resettlement of the rest of them within "Operation Vistula" to the east and north of Poland, had a great impact on their spiritual and material culture. ${ }^{1}$ Shrines, cemeteries, roadside shrines, and buildings of cultural and educational Ukrainian organisations, as well as farm buildings, were left behind. They constituted a permanent element of the town's landscape and served the inhabitants in their daily lives. The resettlement of the inhabitants changed the meaning of these structures. They ceased to be public facilities and became a symbol of the spiritual bond between the deported and their lost homeland. They were a sign of the multinational and multi-denominational nature of that land. However, the absence of an owner made it easier for them to be ruined, both by people and nature. Their fates varied: some were destroyed, others were saved.

\footnotetext{
${ }^{1}$ For details see: DROZD, Roman. Ukraincy wobec swojej przeszłości (1947-2005). Słupsk-Warszawa: Zakład Wydawniczy Tyrsa, 2013; short version of the article: DROZD, Roman. Losy cerkwi greckokatolickich i prawosławnych w Polsce w latach 1944-1989. In: Lemkowie, Bojkowie, Rusini-historia, współczesność, kultura materialna i duchowa, t. V, red. B. Halczak, S. Dudra, R. Drozd and others, Słupsk-Zielona Góra-Svidnik:Oficyna Wydawnicza Uniwersytetu Zielonogórskiego, 2015, pp. 409-420.
} 
For Ukrainian people the most important bonding symbol was the shrine with its characteristic architecture and iconostasis. The previous users of these had been relocated, together with the clergy, which foredoomed their fates. The abandoned buildings were subject to devastation and consequently to destruction and those that were taken over by new owners were adapted to their needs. Resumption of Orthodox religious services and activity by the Greek Catholic Church would have been the best solution for them. However, it was impossible in the political and ideological climate of that time, the more so because the authorities aimed to consolidate the situation caused by Operation Vistula. After 1946, the Polish authorities ceased to acknowledge the existence of the Greek Catholic Church as a consequence of the Lviv Sobor in 1946, which formally liquidated it in the USSR. Moreover, the Polish authorities counteracted the establishment of Orthodox parishes in the areas where Ukrainians had been deported from. Liberalisation of the policy towards those religious communities occurred after 1956, together with the political thaw in Poland caused by the June events in Poznan and changes in the top authorities, which were linked to Władysław Gomułka resuming the leadership as the first secretary of the Polish United Workers' Party (PZPR).

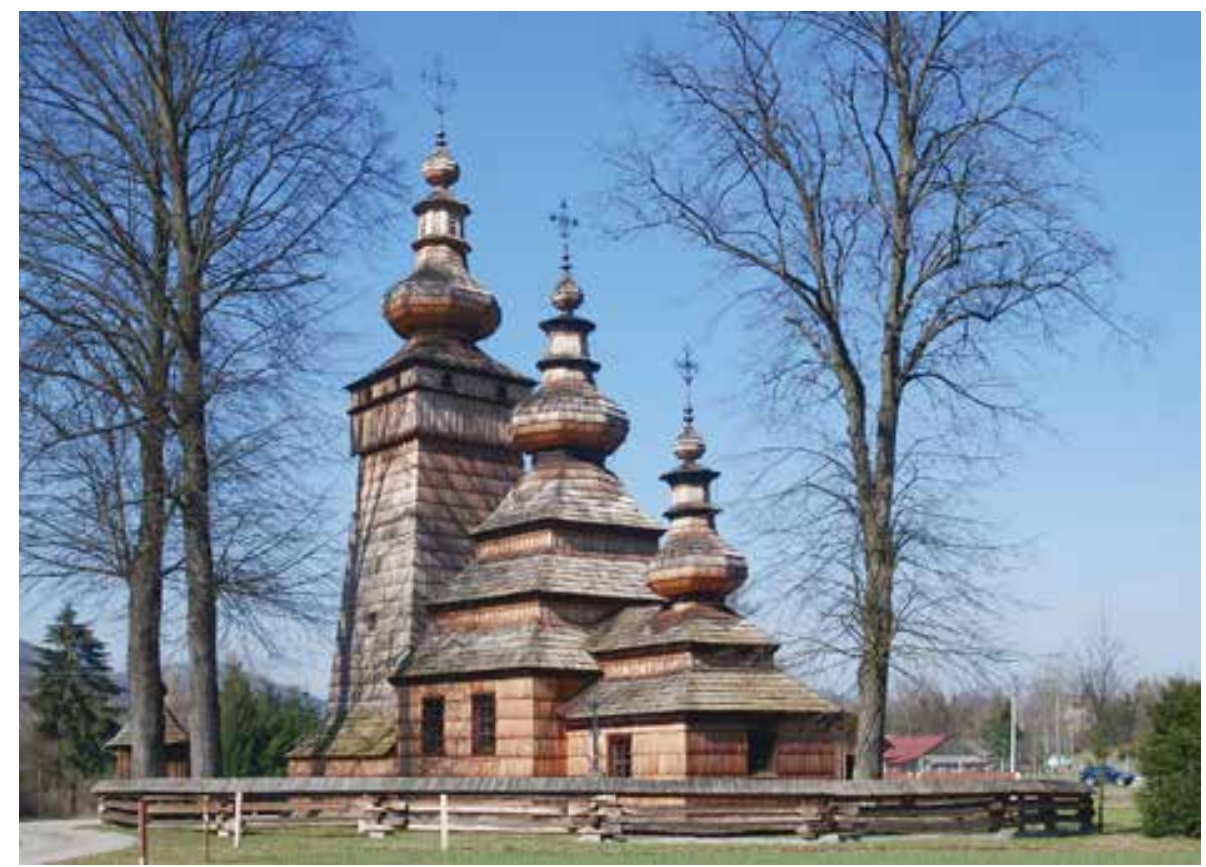

Fig. 1: Greek Catholic Church of St. Paraskewy in Kwiaton

(https://upload.wikimedia.org/wikipedia/commons/2/23/Kwiato\%C5\%84\%2C_ cerkiew_\%C5\%9Bw._Paraskewy_\%28HB1\%29.jpg)

The recovery of the Greek Catholic Church after 1956 and the establishment of new Orthodox parishes for Ukrainian people took place mainly in western and northern Poland. This meant that the shrines were left without supervision and their fates depended on many factors including the attitudes of the Roman Catholic Church, the local Polish community, and the authorities. During the resettlements of Ukrainian people to the Russian Ukraine, the authorities and the Roman Catholic Church made every effort to take over the Greek Catholic 
properties, which soon led to disputes. ${ }^{2}$ The state and the Roman Catholic Church taking over Greek Catholic shrines was not well perceived by the Ukrainian people. On the one hand, they felt robbed, and on the other hand, they felt convinced that there was a "collusion of all the Polish forces aiming to destroy the Ukrainian minority in Poland" because the authorities and a part of the Roman Catholic clergy impeded the provision of religious services, especially the Greek Catholic ones. ${ }^{3}$ Therefore, all information about the demolition or destruction of a shrine was perceived in this way, as it indicated the erasure of all traces of a centuries-old way of life in this area.

Disagreements between the Roman Catholic Church and the authorities about Church property were also perceived in a negative way as the property was not considered to belong to either party. On 5 September 1947, the authorities issued a decree which enabled the state to take over property owned by a legal person or entity whose existence or activity became inoperative as a result of resettlement of their members to the USSR. It was amended on 28 September 1949. Although there was no act de-legalising the Greek Catholic Church, and the Orthodox Church still existed in Poland, their property was taken over by the authorities by decree. The Roman Catholic Church did not agree to that solution as they strove to take over the property of the Greek Catholic Church themselves. They assumed that the property of the Greek Catholic Church, as part of the Catholic Church, belonged to the common Catholic Church, that is, the Roman Catholic Church.

The negative attitude of the authorities led the Roman Catholic Church to arbitrarily take over the Greek Catholic shrines, mostly in towns inhabited by Roman Catholics. Takeovers also occurred in Tarnów diocese from 1946. Similarly, Bishop Jan Stepa was able to establish 22 parishes in Lemkivshchyna in December 1951. A few more shrines were joined to them as auxiliary churches. In some cases, several shrines were assigned to one parish church, thus obtaining a new owner and host. The Ukrainian community disapproved of such action. They perceived it as taking over their property and did not consider the fact that finally there was someone to take care of the shrines and protect them from decay. At the beginning, the relocated Ukrainians were constantly thinking about return and waiting for the right moment. On their return, the buildings and shrines were to serve their needs again. Their takeover by the Church limited such a possibility or even made it impossible. Only after the Ukrainians ceased to think about returning did they begin to see the other side of the issue. They realised that being taken over by the Church was the only way their shrines would survive. In western Lemkivshchyna, only one shrine in Kamianna, built in 1805, was not taken over, but instead was moved to Bukowiec in the Rożnów Foothills. However, its character as a historical relic and a shrine was destroyed during its reconstruction. Unfortunately, this was done with the permission of a historic preservation expert. In eastern Lemkivshchyna, not many shrines were taken over and those left unattended soon went into decline. ${ }^{4}$

The situation was similar in Przemyśl diocese. There were 70 shrines in use in March 1962. Bishop Ignacy Tokarczuk, the successor of Przemyśl bishop Franciszek Barda, became

\footnotetext{
${ }^{2}$ MISILO, E. (ed). Repatriacja czy deportacja. Przesiedlenie Ukraincón z Polski do USRR 1944-1946,T. II. Dokumenty 1946. Warszawa: Oficyna Wydawnicza „Archiwum Ukraińskie”, 1999, doc. 9. p. 22; see also: WOJEWODA, Zbigniew. Zarys historii Kościoła greckokatolickiego w Polsce w latach 1944-1989. Kraków: Zakład Wydawniczy Nomos, 1994, pp. 53-62; Losy cerkwi w Polsce po 1944 roku. Rzeszów: Stowarzyszenie Historyków Sztuki, 1997.

${ }^{3}$ SKÓRKA, Mirosław. Wspólne sąsiedztwo czy nie chciani intruzi? In: Wię́, no. 3, 1998, p. 74.

${ }^{4}$ KORNECKI, Marian. Losy cerkwi i zabytków sztuki cerkiewnej w dawnym województwie krakowskim 19451975. In: Losy cerkwi w Polsce po 1944 roku, Rzeszów: Stowarzyszenie Historyków Sztuki, 1997, pp. 106-107.
} 
infamous for taking them over, both legally and illegally. ${ }^{5}$ Nonetheless, the authorities preferred to demolish them rather than to allow them to be used for religious purposes. On 20 June 1963, the Board of the Provincial People's Council (PWRN) in Rzeszów passed a resolution on demolishing the shrines in Pawłokoma and Wołodź (Brzozów County ${ }^{6}$ ), and on 17 August a year later those in Myszków (Lesko County), Dubieck, Iskań, Orzechowce, Ujkowice, and Żurawica (Przemyśl County ${ }^{\top}$ ). In 1967, the authorities intended to demolish the shrine in Nakło (Przemyśl County) but the demolition crew were stopped by the residents of the village, led by Mikołaj Owczar, the village head, who was soon removed from office. ${ }^{8}$ In April 1967, bishop I. Tokarczuk notified the PWRN of his wish to take over 46 shrines. After receiving a negative reply, he ordered the local priests to take over some of the shrines without permission and presented a list of 17 of them in 1969. Talks with the authorities resulted in getting permission to take over 13 shrines while the rest were occupied without permission. Overall, Przemyśl Diocese used 167 Greek Catholic shrines in the years 1945-1985'.

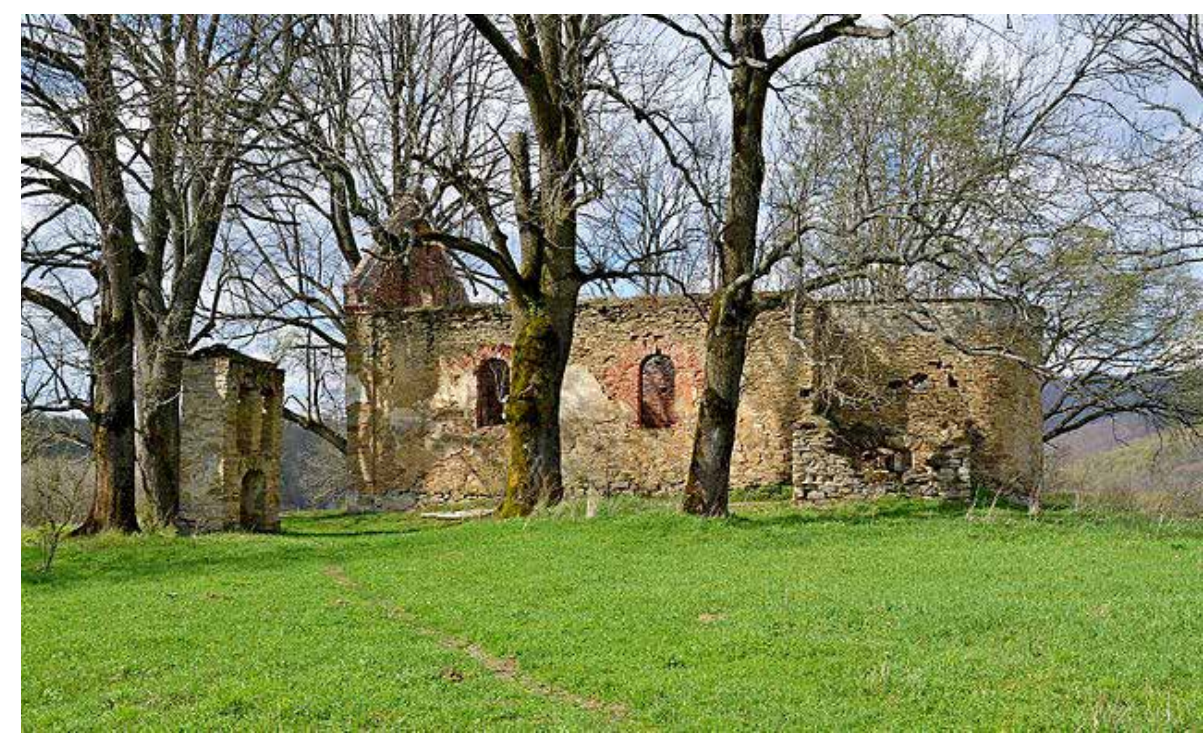

Fig. 2: Ruins of the Greek Catholic Church of St. Paraskeny in Krive

(https://upload.wikimedia.org/wikipedia/commons/thumb/0/09/ Krywe_\%28\%D0\%9A\%D1\%80\%D0\%B8\%D0\%B2\%D0\%B5\%29_-_ruins_of the_church.jpg/640px-Krywe_\%28\%D0\%9A\%D1\%80\%D0\%B8\%D $0 \%$ B $2 \%$ D0 $\% \bar{B} \% 29$ _-_ruins_of_the_church.jpg)

Obviously, it would be an oversimplification to claim that this taking over of shrines was what saved them. Although it was true in many cases, there were exceptions as well. Priest Franciszek Stopa, who settled in Polańczyk (Lesko County) in 1948, supervised 18 shrines. Because they were situated in a large area, he was not able to protect them. As a consequence, 9 of them had ceased to exist by 1956 and two of them had begun to decay. Yet, it must be

\footnotetext{
${ }^{5}$ BOBER, Sabina. Spór o cerkwie greckokatolickie w diecezji przemyskiej za rządów biskupa Ignacego Tokarczuka. In: Biuletyn Ukrainoznawcsy, no. 6, 2000, pp. 118-124.

${ }^{6}$ Archiwum Akt Nowych (AAN), f. Urząd do spraw Wyznań (Ud/sW), sygn. 67/46.

7 AAN, f. Ud/sW, sygn. 68/39.

${ }^{8}$ Archiwum Państwowe w Przemyślu (APPrz) f. Prezydium Powiatowej Rady Narodowej w Przemyślu (PPRNPrz), sygn. 1157.

${ }^{9}$ WOJEWODA, Zarys historii Kościoła..., p. 64.
} 
emphasised that it was the result of the authorities' policy to a large extent, as they treated the Church as a political enemy and aimed to eviscerate it. There was no permission to build new places of worship, and shrines were demolished or devastated. Moreover, measures were taken to remove Greek Catholic shrines formerly taken over by the Church. ${ }^{10}$

In many towns — as Ryszard Brylowski said — the padlocks on the shrine doors changed from "church" to "state" ones and back again. The 'management' of the uniate shrines (by the state) involved their profanation, devastation and demolishing or changing them into warehouses, which in no way protected them. They were improperly used for years (e.g., as warehouses for artificial fertilisers or sheepfolds) and never renovated and when they were dilapidated, they were simply abandoned and demolished. Some of the churches were thoroughly redeveloped by new owners, which erased their style and liturgical character. ${ }^{11}$

The takeover of a shrine by the Roman Catholic Church often entailed necessary changes to its décor. The changes often involved the iconostasis. Several methods were used. Some of the shrines were completely or partly dismantled and others were preserved, especially those which served as auxiliary churches, while in others an altar was placed in front of the iconostasis. ${ }^{12}$ Some iconostases were destroyed, such as those in the shrines in Lubaczów, Liski, and Szepiatyń (Hrubieszów County), inter alia. Also, some shrines were abandoned after many years of exploitation without repairs such as those in Korczmin, Tarnoszyn (Tomaszów County), and Miękisz Stary (Jarosław County) $\cdot{ }^{13}$ In the former Orthodox cathedral in Chełm, currently the Church of Virgin Mary, all traces of its eastern past were removed. Cyrillic inscriptions were even removed from the bells. ${ }^{14}$ Orthodox Church works of art, especially icons, were destroyed or they were stolen and passed on to specially created repositories for icons in Sanok, Biecz, and Lańcut in order to protect them. Barbara Tondos, enthusiastically involved in the protection of shrines and icons, who participated in exploratory expeditions in 1957-1959 said: "During the exploratory expedition [...] many shrines still had their complete décor from tablecloths on the altars, candles in the candelabra to the remains of incense in the thuribles". It was then that intensive exploration of the Bieszczady and the Beskidy Mountains was begun by the seekers of icons and figures of saints. Sometimes interiors left unspoilt for some time were one day found to be ruined, with only the faces of saints cut out from the icons scattered around. Such was the case in Ustianowa Dolna, in Nowe Sady. ${ }^{15}$

The issue of taking over the Greek Catholic Church property sparked conflicts right from the beginning and became even more controversial for two reasons. The first was the more and more active Greek Catholic clergy and the second was the Orthodox Church, which aimed to set up a network of places of worship. The complexity of this issue is reflected in the case

\footnotetext{
${ }^{10}$ BRYKOWSKI, Ryszard. W sprawie architektury cerkiewnej województwa rzeszowskiego po 33 latach. In: Losy cerkwi w Polsce po 1944 roku. Rzeszów: Stowarzyszenie Historyków Sztuki, 1997, pp. 144-147.

${ }^{11}$ Ibidem, pp. 146-147.

${ }^{12}$ KORNECKI, Losy cerkwi..., pp. 107-108.

${ }^{13}$ CZECH, M. (ed). Ukraincy w Polsce 1989-1993. Kalendarium. Dokumenty. Informacje. Warszawa: Zakład Wydawniczy Tyrsa, 1993, doc. 9, pp. 86-98.

${ }^{14}$ Nasze Słowo, 17 November 1991.

${ }^{15}$ TONDOS, Barbara. Ochrona cerkwi na granicach legalności. In: Losy cerkwi w Polsce po 1944 roku, Rzeszów: Stowarzyszenie Historyków Sztuki, 1997, p. 125.
} 
of the Orthodox Church's takeover of the Greek Catholic cathedral and the building of their Chapter in Przemyśl. The Roman Catholic, the Greek Catholic, and the Orthodox Churches, as well as the central and local authorities, were all involved in this case. Eventually, the authorities accepted the takeover of the cathedral by the Carmelite Brothers after the intervention of Józef Cyrankiewicz, the prime minister. ${ }^{16}$

The attitude of the authorities towards the activity of the Greek Catholic Church in Rzeszów Province changed after 1956 because the local Greek Catholics demanded religious services conducted in accordance with their own rite. It constituted a real danger for the authorities as there were already Greek Catholic priests in the area such as Jan Wysoczański and Zenon Złoczowski. They were permitted to start pastoral activity in that region based on the Roman Catholic Church. Moreover, the authorities wanted to prevent their major ideological enemy, the Roman Catholic Church, from getting stronger. Therefore, they chose the lesser evil and agreed to establish Orthodox parishes, which fit with the policy of the Orthodox Church taking over from the Greek Catholics. It was the best possible solution for the churches at that time, as it secured them, but did not require a change of their décor.

For the Orthodox Church, it was an opportunity to strengthen their position and resume activity. One must remember that there had been Orthodox shrines, separate from the Greek Catholic ones, in Lemkivshchyna until 1947. Macarius, the metropolitan bishop, ordered priest Jan Lewiarz to make a few inquiries as to whether it would be possible to establish Orthodox parishes in Rzeszów Province. Then, they set out to establish such parishes, mainly in that province. They made a breakthrough in the years 1958-1959 when 14 parishes were established (Bartne, Blechnarka, Bodaki, Bóbrka, Hańczowa, Hłomcza, Kalników, Kłokowice, Kwiatoń, Młodowice, Regetów Niżny, Sanok, Wysowa, and Zagórz), which was possible thanks to the return of a substantial number of Ukrainians. In 1958, a mission committee was set up in the archdiocese and Rzeszów Deanery was established a year later. However, the action by the Orthodox Church to take over the Greek Catholic establishments (the so-called mission action) encountered numerous difficulties. Most Polish people and the local authorities opposed it, especially in Rzeszów Province, as neither of them wanted to see Greek Catholic or Orthodox institutions in the area. On the other hand, the central and local authorities did not agree to strengthen the Greek Catholic Church in Lublin Region. The Ukrainian people in this area were Greek Catholics and establishing new parishes could have only encouraged Ukrainians from the west and east to return. Therefore, the Department of Religious Denominations of the PWRN in Lublin opposed the establishment of new places of worship and suggested that the Greek Catholic establishments, which had been taken over by various institutions, should be "demolished or rebuilt so that they lose their former appearance". ${ }^{17}$ Following this order, the authorities demolished shrines in Siedliska (Zamość Province) and Tymoszewice (Tomaszów Province). ${ }^{18}$ Nevertheless, the structure of the Orthodox Church was slowly but methodically restored in Lublin Region. In 1969, there were 14 parishes, six of which had their own branches, and the congregation was estimated at 5,300 followers. ${ }^{19}$

\footnotetext{
${ }^{16}$ See: DROZD, Roman. Problem własności byłej katedry greckokatolickiej w Przemyślu w latach 1946-1996. In: Scripta Historica, 2018, pp. 237-253.

${ }^{17}$ AAN, f. Ud/sW, sygn. 24/18.

${ }^{18}$ WYSOCKI, Jacek. Ukraincy na Lubelszçyźnie w latach 1944-1989. Lublin: Instytut Pamięci Narodowej Oddział Lublin, 2011, p. 180.

${ }^{19}$ WYSOCKI, Ukraincy na Lubelszrcyyźnie..., p. 176.
} 
The Orthodox Church's growth in strength must have sparked a response from the Roman Catholic Church and the Greek Catholic clergy. The latter were afraid of losing their followers, which would result in the elimination of the liturgical rite in the area. On the other hand, the Roman Catholic Church perceived it as a threat to their property in south-east Poland. Establishing Orthodox institutions posed the danger of losing the taken-over Greek Catholic Church property, especially their places of worship. Because of that, both liturgical rites tried to prevent the development of the Orthodoxy. The Greek Catholic clergy wanted to provide pastoral services for their followers on the basis of the Roman Catholic parishes as soon as possible. In contrast, the Roman Catholic Church used the Greek Catholic clergy for this purpose, allowing them to hold services occasionally just to prevent the establishment of new Orthodox parishes.

The activities of the Greek Catholic and Roman Catholic clergy in this area made the actions of the authorities in supporting the Orthodox Church more determined. On 5 July 1961, the functionaries of the Security Service cunningly manoeuvred matters to close the shrine in Komańcza. After numerous protests by the Greek Catholics as well as Cardinal Wyszyński, the shrine was reopened but as an Orthodox one. Amidst fears that people would switch to Orthodoxy, the Greek Catholic services were moved to the local Roman Catholic church. ${ }^{20}$ The shrine in Krempna was also closed on 4 July 1962. ${ }^{21}$ The authorities were also planning to close the shrine in Szczawne (Sanok County) and then pass it on to the Orthodox Church. The Department of Religious Denominations $(\mathrm{Ud} / \mathrm{sW})$ planned a similar action concerning the Garrison church in Przemyśl where Greek Catholic services were held. ${ }^{22}$

Archbishop Stefan, the new Orthodox metropolitan, was interested in the Orthodox matters in Rzeszów Region. In November, he sent a list of 23 shrines to the Chairman of the PWRN in Rzeszów together with a request to pass them on to the Orthodox Church. These included shrines in Bielanka, Dziurdziów, Hołuczkowo, Chotyniec Konieczna, Krempna, Kulaszne, Lesko, Leszczyny, Olechowiec, Pikulice, Polany, Posada Rybotycka, Turzańsk, Zapałów, Siemuszowa, Zdynia, and Przemyśl. ${ }^{23}$ Obviously, handing over shrines to the Orthodoxy led to conflicts with the Catholics of both liturgical rites which soon became ethnic conflicts stoked by the local authorities. Several well-known conflicts occurred: Hłomcza (Sanok County), Kalników (Przemyśl County), Kunkowa, Rozdziel (Gorlice County), and the best-known in Polany (Jasło County). The last of these, lasting for a few years, led to direct correspondence between the primate of Poland and the Orthodox metropolitan bishop and even became known internationally, casting a shadow over the authorities' policy towards the Ukrainian people. ${ }^{24}$

Unfortunately, the shrines' situation deteriorated in the 1970s and 1980s as they were abandoned, left unattended and sometimes used for economic purposes. In 1972, the authorities decided to resolve the problem. By the order of the Central Committee of the Polish United Workers' Party (PZPR), the Department of Religious Denominations (Ud/sW) prepared a "note on the shrines situated in south-east provinces". According to incomplete data, 206 shrines followed the Latin rite, 31 shrines followed the Orthodox rite, 39 shrines were used by national and cooperative institutions, and 65 shrines were not used at all. In Cracow

\footnotetext{
${ }^{20}$ See: AAN, f. Ud/sW, sygn. 131/283.

${ }^{21}$ See: $A A N$, f. Ud/sW, sygn. 45/567.

${ }^{22}$ See: AAN, f. Ud/sW, sygn. 127/56.

${ }^{23} \mathrm{AAN}, \mathrm{f}$. Ud/sW, sygn. $127 / 56$.

${ }^{24}$ See: AAN, f. Ud/sW, sygn. 131/421; URBAN, Kazimierz. Kościót prawosławny w Polsce 1945-1970. Kraków: Zakład Wydawniczy Nomos, 1996, p. 316.
} 
Province, the Roman Catholic Church took over 32 out of 35 existing Greek Catholic shrines (including one in Cracow) whereas the other three were deserted and deemed not fit for use. ${ }^{25}$ In Lublin Province, the Latin liturgical rite used 35 Orthodox shrines, while four others (former warehouses) were destroyed. $\mathrm{Ud} / \mathrm{sW}$ petitioned for the immediate demolition of those ruined shrines which were not historical monuments, and also to delete devastated shrines from the register of class III and IV historical monuments. The shrines which were fit for use were to be transferred to open air museums and ten of them were to be passed on to the Roman Catholic Church. ${ }^{26}$ The next several years of that plan led to the disappearance and destruction of more shrines from the landscape of south-east Poland. Also, the proceedings on destroying historical shrines were discontinued by the Attorney General in 1957 due to the "insignificant harm to society" of the acts. As early as 1980, the shrine in the village of Rajskie (Lesko County) was blown up, while one in Paniszczewo (Lesko County) was destroyed during its transport from Lutowiska to Dwernik (Bieszczady County). The shrine in Lipie (Bieszczady County) was burnt down as well. ${ }^{27}$ Understandably, the information about destroying the shrines reached the Ukrainians and strengthened their conviction that the Poles aimed to erase the traces of material Ukrainian culture in this area. Their conviction was not unfounded. In August 1977, the Ministry of Administration, Economy, and Environment Protection changed the names of about 120 Ukrainian villages and towns, which was met with opposition not only from the Ukrainian community but also from the Polish Science Academy and the Polish Writers' Union. For the next few years, the words of opposition were left unheard, but in 1981 the authorities decided to bring back most of the old Ukrainian names of these towns and villages. ${ }^{28}$

According to research conducted in the Roman Catholic Przemyśl diocese there had been 552 shrines before the war. In the years 1939-1947 nine of them were destroyed, and four burnt down as a result of unintentional fires after 1956. Thus, after Operation Vistula, 240 shrines were destroyed (140 before 1956 and the other 53 later). The destruction dates of the other 47 shrines are not known. Two hundred and fifty-three of the remaining shrines served religious purposes while ten became museums. Thirty-nine shrines were not used and 11 of them fell into decay. The local people took care of one shrine, one served as a theatre, and three as warehouses, and there is no available data about the other three. Nine shrines were completely transformed, which is why the number of shrines decreased to 269. Many valuable historical relics were lost irrevocably, including two shrines from the sixteenth century, nine shrines from the seventeenth century, 40 shrines from the eighteenth century, 141 shrines from the nineteenth century and 60 shrines from the twentieth century. It was impossible to determine the time of construction for one of the buildings. Nevertheless, it was shocking that intentional destruction of the shrines continued until the end of the Polish People's Republic (PRL). ${ }^{29}$ Unfortunately, the data concerning Orthodox shrines in the area covered by Operation Vistula is not available. That is because there is not enough knowledge about the number of shrines demolished or taken over by the Roman Catholic Church in the inter-war period. According to the pre-war Provincial Office in Lublin, the Roman Catholic Church had taken over 144 shrines

\footnotetext{
${ }^{25}$ KORNECKI, Losy cerkwi..., p. 106.

${ }^{26}$ AAN, f. Ud/sW, sygn. 131/283.

${ }^{27}$ BRYKOWSKI, W sprawie architektury..., pp. 151-155.

${ }^{28}$ ZABROWARNY, Stefan. Polityka narodowościowa polskich władz komunistycznych w kwestii ukraińskiej. In: Polityka narodowościowa państw Europy Środkowo-Wschodniej, pod red. J. Pietrasia i A. Czarneckiego, Lublin: Instytut Europy Środkowo-Wschodniej, 1993, p. 147.

${ }^{29}$ BRYKOWSKI, W sprawie architektury..., pp. 155 and pp. 158-161.
} 
including the Sobor Narodzenia Bogurodzicy na Górce in Chełm. However, according to the data from the Orthodox Metropolis in Chełm Region and Southern Podlasie, there were 67 active Orthodox shrines, while 165 were transformed into churches, 96 were closed down, 24 were burnt down, 25 were demolished, four were transformed into schools and one was turned into a house. After 1929, another stage of the demolition of Orthodox shrines began. The plan was to demolish 97 Orthodox shrines but only 23 were actually demolished because of protests by the local people. ${ }^{30}$ From the middle of May to the middle of July 1938, a subsequent operation to demolish Orthodox shrines on a massive scale began. One hundred and twentyseven shrines were demolished at that time. ${ }^{31}$ It is not known how many shrines were recovered by the Orthodoxy in the period of German occupation. According to the map developed by Jerzy Tur included in the book Losy cerkwi w Polsce po 1944 r., it is difficult to determine the year of destruction or even the fate of many destroyed Orthodox shrines except during the interwar period. The seventeenth-century shrine in Lubycza-Kniazie (Tomaszów County) and the eighteenth-century shrine in Teniatyski (Tomaszów country) were in a very bad state and it practically impossible to save. ${ }^{32}$ The study says that there were 123 shrines and 209 buildings in the shrine complexes in the region of Lublin in 1997. The Orthodox Church used 16 of them while the Greek Catholic Church used one of them. The rest were used by the Roman Catholic Church. ${ }^{33}$ On the other hand, Jacek Wysocki claims that in 1967 the Roman Catholic Church used 59 historical Orthodox shrines, including 12 non-historical ones, while 24 were

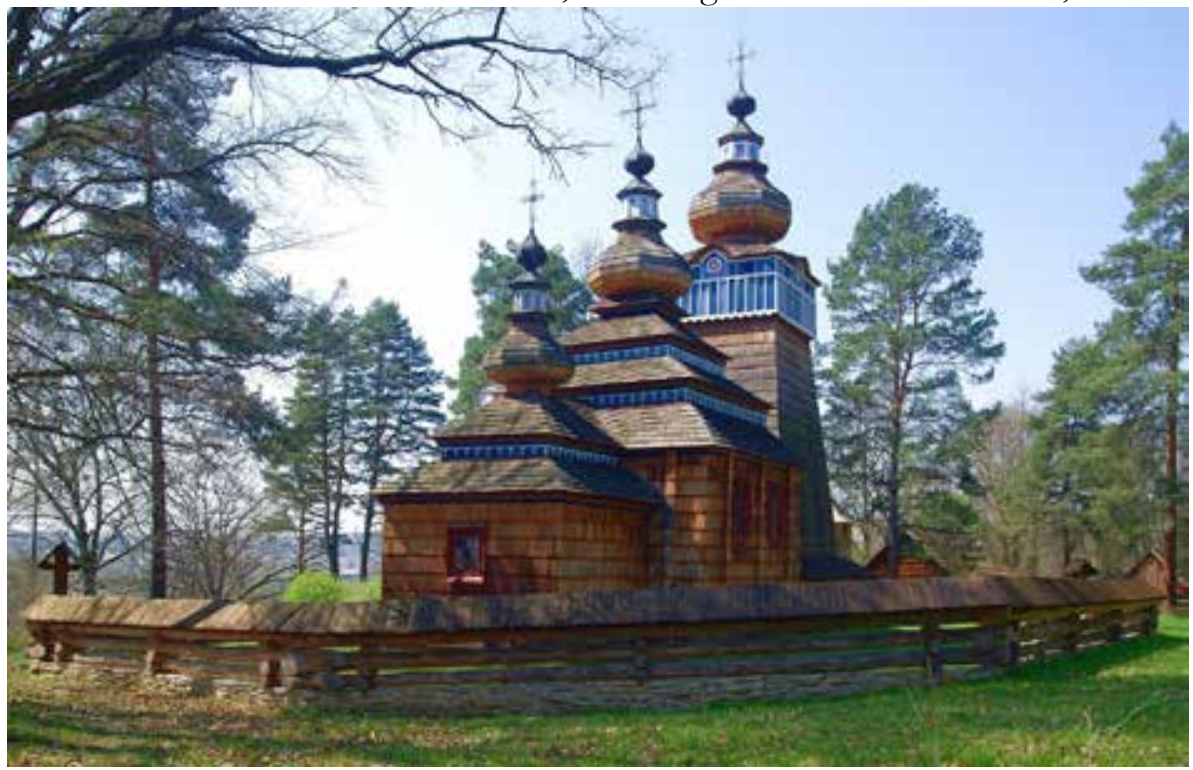

Fig. 3: Greek Catholic Church of the Nativity of the Mother of God in Ropki, currently in the open-air museum in Sanok

(https://upload.wikimedia.org/wikipedia/commons/d/de/Ropki\%2C_cerkiew_ Narodzenia_Bogurodzicy\%3B_obecnie_Park_Etnograficzny_w_Sanoku.jpg)

\footnotetext{
${ }^{30}$ KUPRIANOWICZ, Grzegorz. 1938. Akecja burz̨enia cerkwi prawosławnych na Chetmszçyźnie i Potudnionym Podlasiu. Chełm: Prawosławna Diecezja Lubelsko-Chełmska, 2008, pp. 19-21.

${ }^{31}$ Ibidem, p. 61.

${ }^{32}$ Ukraincy $w$ Polsce, doc. 9. pp. 86-98.

${ }^{33}$ SENIUK, Bronisław. Cerkwie w regionie lubelskim. In: Losy cerkwi w Polsce po 1944 roku, Rzeszów: Stowarzyszenie Historyków Sztuki, 1997, pp. 362-363.
} 
transformed into churches. The Orthodox Church used 20 shrines. $^{34}$

One cannot forget about people and institutions that made efforts to save and protect the shrines from destruction. Historic preservation officers acknowledged the problem, but the possibilities to secure the Orthodox and Greek Catholic shrines were limited due to lack of means, transport difficulties, and depopulation of the area. According to available information, in 1945 the Provincial Historic Preservation Office in Cracow took up administrative measures to secure abandoned buildings; however, there is no concrete data on this. In the years 19471949, the Historic Preservation Office took up action in the area of Cracow Province in order to secure works of church art, mainly icons from buildings which had not been taken over by the Roman Catholic Church yet were exposed to looting and destruction. Dr Hanna Pieńkowska was entrusted with that task. The recovered icons were placed in the repository in Muszyna. After this was closed down, they were taken to the Regional Museum in Nowy Sacz, where they constitute a permanent exposition. Renovations conducted under a preservation officer's supervision took place in shrines used by the Roman Catholic Church since the 1960s. This activity was initiated by Jerzy Ablewicz, the Ordinary of the Tarnów Diocese. Nearly all shrines had been renovated to some extent by 1975. The shrines in Owczary, Męcino Wielkie, and Ropica Górna (Gorlice County) had been thoroughly renovated. Moreover, priest Mieczysław Czekaj had a picturesquely located brick shrine in Bieliczna (Gorlice County) renovated with the help of the local community. In the 1970s, the Historical Monuments Registry Office (Zespół Dokumentacji Zabytków) carried out an inventory of all shrines in Cracow Province. They developed a broad photographic documentation and made filing cards for historical works of church art. Also, comprehensive conservation works were carried out in the Greek Catholic shrine in Powroźnik (Nowy Sącz County), and the icons in Berest (Nowy Sącz County), collected by a local priest, were renovated as well. ${ }^{35}$

In Rzeszów Province, icon repositories were set up during the 1940s and 1950s. One was set up in Sanok, another one in Biecz (Gorlice County), and one in the shrine in Kotań (Jasło County). The idea was initiated by Bogdan Treter, Hanna Pieńkowska, and Józef Dutkiewicz. Unfortunately, some of their co-workers were more interested in the financial aspect than actual preservation of the icons. In 1957-59, explorations were organised in all the counties where Greek Catholic and Orthodox shrines were found. These were mainly conducted by students of Slavic studies from Jagiellonian University, initially supervised by Feliks Wolski, an art historian, and then by Barbara Tondos. Their tasks were to describe everything they had seen in the shrines and chapels and to make drawings in some cases. The whole enterprise was organised by Jerzy Tur, the Provincial Historic Preservation Officer, in cooperation with Aleksander Rybicki, who was setting up the Museum of Folk Architecture in Sanok at that time. In 1969, an icon repository was established in the Museum in Lańcut. Individual icons and also whole iconostases were brought there under the supervision of B. Tondos, mentioned above. As a result, a lot of icons were saved from dilapidation and theft. In the 1960s and 1970 s, many icons were stolen from both unused and active shrines, as interest in icons was growing because of their artistic and historical value ${ }^{36}$.

In 1965, Stanisław Latałło created a short film for the newsreel. This was the first dramatic public voice defending Greek Catholic and Orthodox shrines. An idea considered in 1968-1972

\footnotetext{
${ }^{34}$ WYSOCKI, Ukraincy na Lubelszczyźnie..., p. 181.

${ }^{35}$ KORNECKI, Losy cerkwi..., pp . 108-111.

${ }^{36}$ WYSOCKI, Ukraincy na Lubelszçyźnie..., p. 179.
} 
was to set up an open-air museum of Greek Catholic and Orthodox shrines in the Bieszczady Mountains. The idea was abandoned and in the following years the issue of saving Greek Catholic and Orthodox shrines was passed over in silence due to the attitude of the central and local authorities. ${ }^{37}$ Olgierd Lotoczko took up the cause of saving the Greek Catholic shrine in Lopienka (Lesko County) in the 1970s. However, the collateral security turned out to be insufficient and the shrine underwent another renovation by Zbyszek Kaszuba in 1986, albeit with many difficulties. Finally, Zofia Szanter saw to the complete renovation of the shrine in Przyslupie (Gorlice County). ${ }^{38}$

Unfortunately, not all people responsible for securing historical monuments discharged their tasks properly. Due to a lack of a historic conservator's supervision, the historical shrine in Kamianna lost its liturgical character and thus its historical value after it was transferred to Bukowiec in Pogórze Rożnowskie with the consent of the historic preservation officer. The same happened to the shrine in Klimkówki (Gorlice County) whose transfer was necessary because of the construction of a dam. ${ }^{39}$ In 1968, during the filming of the fire scene in Raszków for the film "Colonel Wolodyjowski” (Polish: Pan Wołodyjowski), there was a plan to burn down the church in Chmiel (Bieszczady district). This concept was approved of by the Voivodeship Conservator of Monuments in Rzeszów, Jan Górak. Only the intervention by Maria Ziębińska, the County Historic Preservation Officer from Przemyśl, B. Tondos, and Professor Jerzy Szablowski, the film consultant, prevented such barbarity. Nevertheless, J. Górak's tenure, albeit short, led to the destruction of several historical monuments. ${ }^{40}$ The most glaring examples of destroying shrines are:

- in 1980, the nineteenth-century shrine in Lutowiska was destroyed under the pretence of transferring it and the material was used to build a church in Dwernik (Bieszczady County);

- a year later, the shrine in Lipie, dating from 1900, burnt down (Przemyśl County);

- in 1984, the shrine in Załuże (Lubaczów County), dating from 1700, burnt down together with very valuable equipment, as well as the belfry in Machnowo Stare (Tomaszów County);

- in 1985, the shrine in Kościaszyn (Hrubieszów County) was destroyed;

- in 1986, the oldest freestanding wooden belfry in Myscowa, dating from 1760, was dismantled (Jasło County);

- in 1987, the shrines in Dyniska (Tomaszów County) and in Eukawiec (Lubaczów County) burnt down;

- in 1988, the shrine in Majdan Sieniawski (Przeworsk County) was burnt down. ${ }^{41}$ Also, the shrine in Bobrówka (Jarosław County) was dismantled by the parish in Ryszkowa Wola under the pretence of its renovation, with the "total indifference" of Marek Gosztyła, the provincial historic preservation officer from Przemyśl. ${ }^{42}$ According to the Ukrainian Social and Cultural Association (a licenced and legally operating Ukrainian association in the PRL), most renovations of Greek Catholic and Orthodox shrines performed by Roman Catholic parishes were not done with the consultation of historic preservation officers, which led to the degradation of the shrines in Sulimów (Hrubieszów Couny) and Bihale (Lubaczów County). In the area of Zamość Province, only two shrines in Hrubieszów and Tomaszów Lubelski owned

\footnotetext{
${ }^{37}$ TONDOS, Ochrona cerkwi..., pp. 122-131.

${ }^{38}$ Ibidem, pp. 132-133.

${ }^{39}$ KORNECKI, Losy cerkwi..., pp. 106-107.

40 TONDOS, Barbara: Ochrona cerkwi..., pp. 129-130.

${ }^{41}$ Ukraincy w Polsce, doc. 9.pp. 86-98.

${ }^{42}$ BRYKOWSKI, W sprawie architektury..., p. 155.
} 
by the Orthodox Church were renovated under the supervision of a historic preservation officer. In the area of Zamość Province at that time, only two Orthodox shrines-in Hrubieszów and Tomaszów Lubelski-were renovated under the supervision of a conservator. In the 1980s in Przemyśl Province, only the renovations of the sixteenth-century shrine in Posada Rybotycka (Przemyśl County) and the nineteenth-century shrine in Przemyśl in Wilczańska Street did not lead to the destruction of the body and interior of the shrines. Also, the Greek Catholic parish in Komańcza got permission to transfer the wooden shrine from Dudyńce (Sanok County) to Komańcza. Consequently, a three-level brick shrine was built and the material from the shrine in Dudyńce was used to build its last level. ${ }^{43}$

Evaluating the destruction of shrines, it is impossible to deny the words of R. Brykowski who said:

It is hard to clearly establish how much real and how much 'political', in-line-party-action ignorance there was and who was the more ignorant: the political party comrade in office encouraging and allowing the destruction of the shrines and the executor of his orders, the State Agricultural Farm (PGR) director or the highlander right from the Tatra Mountains who kept his flocks of sheep in the deserted churches covering the windows with icons from the fifteenth or sixteenth century. However, the actions of the primitive shepherd may be explained though not justified by his lack of education, his religious upbringing and archaic, adverse, even hostile attitude to everything that is different and unknown, which provokes him with its otherness to destroy. ${ }^{44}$

Summing up, it is important to say that the fate of the Greek Catholic and Orthodox shrines in Poland was the result of the nationalistic policy of the Polish communist authorities which aimed to convert Poland into a one-nation state on the one hand, and to give only Polish character to the areas from which the Ukrainian people had been deported on the other. Such an attitude led to the complete destruction of several hundred shrines as their existence evidenced the multinational and multi-denominational character of the lands. Only a few, which were transferred to open-air museums or were declared to be themselves museums, survived, and constitute one of the most beautiful types of museum attraction. On the other hand, the takeover of the shrines by the Roman Catholic Church saved most of them from being destroyed and ruined but their décor was frequently adjusted to the needs of the Roman Catholic rite. Nevertheless, several hundred shrines survived, especially in Lemkivschyna, thanks to this. The best solution was when they were taken over by the Orthodox Church. The similarity of the two denominations did not require changes to the external or internal appearance of the shrines. The preserved shrines evidence the deep spirituality of the believers and multi-cultural character of the south-east Poland.

\section{References}

Archive sources

AAN - Archiwum Akt Nowych

f. Urząd do spraw Wyznań (UdsW)

\footnotetext{
${ }^{43}$ BRYKOWSKI, W sprawie architektury..., pp. 156-157.

${ }^{44}$ BRYKOWSKI, W sprawie architektury..., p. 149.
} 
APPrz - Archiwum Państwowe w Przemyślu

f. Prezydium Powiatowej Rady Narodowej w Przemyślu (PPRNPrz),

\section{Literature}

BOBER, Sabina (2000). Spór o cerkwie greckokatolickie w diecezji przemyskiej za rządów biskupa Ignacego Tokarczuka. In: Biuletyn Ukrainoznawczyy, no. 6, pp. 118-124.

BRYKOWSKI, Ryszard (1997). W sprawie architektury cerkiewnej województwa rzeszowskiego po 33 latach. In: Losy cerkwi w Polsce po 1944 roku. Rzeszów: Stowarzyszenie Historyków Sztuki, 1997.

CZECH, M. (ed.) (1993). Ukraincy w Polsce 1989-1993. Kalendarium. Dokumenty. Informacje. Warszawa: Zakład Wydawniczy Tyrsa.

DROZD, Roman (2015). Losy cerkwi greckokatolickich i prawosławnych w Polsce w latach 1944-1989. In: Łemkowie, Bojkowie, Rusini-historia, współczesność, kultura materialna i duchowa, t. V, red. B. Halczak, S. Dudra, R. Drozd and others, Słupsk-Zielona GóraSvidnik: Oficyna Wydawnicza Uniwersytetu Zielonogórskiego, pp. 409-420.

DROZD, Roman (2018). Problem własności byłej katedry greckokatolickiej w Przemyślu w latach 1946-1996. In: Scripta Historica, pp. 237-253.

DROZD, Roman (2013). Ukraincy wobec swojej pržeszłości (1947-2005). Słupsk-Warszawa: Zakład Wydawniczy Tyrsa.

KORNECKI, Marian (1997). Losy cerkwi i zabytków sztuki cerkiewnej w dawnym województwie krakowskim 1945-1975. In: Losy cerkwi w Polsce po 1944 roku, Rzeszów: Stowarzyszenie Historyków Sztuki, pp. 93-120.

KUPRIANOWICZ, Grzegorz (2008). 1938. Akcja burzenia cerkwi prawosławnych na Chetmsz̨̧yźnie i Południowym Podlasiu. Chełm: Prawosławna Diecezja Lubelsko-Chełmska.

Losy cerkwi w Polsce po 1944 roku (1997). Rzeszów.

MISIŁO, E. (ed.) (1999). Repatriacja czy deportacja. Przesiedlenie Ukrainców z Polski do USRR 1944 1946. T. II. Dokumenty 1946, Warszawa: Oficyna Wydawnicza "Archiwum Ukraińskie".

Nasze Słowo (1991). 17 November 1991.

SENIUK, Bronisław (1997). Cerkwie w regionie lubelskim. In: Losy cerkwi w Polsce po 1944 roku. Rzeszów: Stowarzyszenie Historyków Sztuki, pp. 347-350.

SKÓRKA, Mirosław (1998). Wspólne sąsiedztwo czy nie chciani intruzi? In: Wię́, no. 3, pp. 70-81.

TONDOS, Barbara (1997). Ochrona cerkwi na granicach legalności. In: Losy cerkwi w Polsce po 1944 roku. Rzeszów: Stowarzyszenie Historyków Sztuki, pp. 121-138.

URBAN, Kazimierz (1996). Kościół prawosławny w Polsce 1945-1970. Kraków: Zakład Wydawniczy Nomos.

WOJEWODA, Zbigniew (1994). Zarys historii Kościoła greckokatolickiego w Polsce w latach 19441989. Kraków: Zakład Wydawniczy Nomos.

WYSOCKI, Jacek (2011). Ukraincy na Lubelsžçyźnie w latach 1944-1989. Lublin: Instytut Pamięci Narodowej Oddział Lublin.

ZABROWARNY, Stefan (1993). Polityka narodowościowa polskich władz komunistycznych w kwestii ukraińskiej. In: Polityka narodowościowa państw Europy Środkowo-W schodniej, ed. J. Pietraś and A. Czarnecki. Lublin: Instytut Europy Środkowo-Wschodniej, pp. 126-148. 